\title{
El procurador y el secretario. El duelo de plumas entre fray Juan Meléndez y don Juan Vélez de León en la corte papal [1680-1684]
}

Resumen: En Roma, entre 1682 y 1683, el procurador dominico peruano y el secretario de la legación española intercambiaron insultos a través de un conjunto de sátiras. El ingenioso y maledicente corpus reveló más que la creciente animadversión entre ambos personajes: develó la tensión y conflicto en varios círculos de poder, la burocracia papal frente a la Corona española, la esfera de influencia de la embajada española y los debates entre hispanoamericanos y europeos respecto de la identidad religiosa indiana. Finalmente, este episodio evidencia la promoción de la agenda cultural de los letrados hispanoamericanos en la república de las letras católica global.

Palabras clave: sátira barroca, santidad hispanoamericana, representación colonial, identidad criolla, letrados coloniales.

\section{The procurator and the secretary. The duel of quills between friar Juan Meléndez and don Juan Vélez de León at the Papal Court [1681-1684]}

Abstract: In Rome, between 1682 and 1683, the Peruvian Dominican Procurator and the Secretary of the Spanish Embassy exchanged bitter satires to ridicule each other. Beyond wit and irony, the poems revealed more than just enmity. Tension and conflict were exposed among members of different cohorts at the Papal Court: the Vatican Curia, corruption and clientelism at the Spanish Embassy, and opposing visions of Spanish-American religious identity for European and Peruvian scholars. Ultimately, the bitter exchange sheds light on Spanish American religious scholars' cultural and political agendas at the center of the Catholic Republic of Letters.

Keywords: Baroque satire, Spanish American sainthood, colonial representation, creole identity, colonial literates.

\section{O procurador e o secretário. 0 duelo de penas entre fray Juan Meléndez e don Juan Vélez de León na corte papal [1680-1684]}

Resumo: Em Roma, entre 1682 e 1683, o procurador dominicano peruano e o secretário da legação espanhola trocaram insultos por meio de uma série de sátiras. 0 corpus espirituoso e malicioso revelou mais do que a crescente animosidade entre os dois personagens: desvelou tensão e conflito em vários círculos de poder, a burocracia papal frente à Coroa espanhola, a esfera de influência da embaixada espanhola e os debates entre hispano-americanos e europeus sobre a identidade religiosa nas Índias. Finalmente, este episódio mostra a promoção da agenda cultural dos letrados hispano-americanos na república das letras católica global. Palavras-chave: sátira barroca, santidade hispano-americana, representação colonial, identidade criolla, letrados coloniais.

Cómo citar este artículo: Carlos Gálvez Peña, "El procurador y el secretario. El duelo de plumas entre fray Juan Meléndez y don Juan Vélez de León en la corte papal [1680-1684]”, Trashumante. Revista Americana de Historia Socia/19 [2022]: $50-73$. DOI: 10.17533/udea.trahs.n19a03

\footnotetext{
Fecha de recepción: 30 de marzo de 2021

Fecha de aprobación: 12 de octubre de 2021
}

Carlos Gálvez Peña: Doctor en Historia por la Universidad de Columbia, Nueva York. Es profesor principal de la Pontificia Universidad Católica del Perú. ORCID: 0000-0003-2755-2545.

Correo electrónico: cgalvez@pucp.edu.pe 


\title{
El procurador y el secretario. El duelo de plumas entre fray Juan Meléndez y don Juan Vélez de León en la corte papal [1680-1684]
}

\author{
Carlos Gálvez Peña
}

En 1680, llegó a Roma como procurador de la provincia dominica de San Juan

EEvangelista del Perú, el limeño fray Juan Meléndez Rodríguez. Llegaba de Madrid, donde había adelantado gestiones relativas a los encargos de su orden, que eran tres de gran importancia: la canonización de sus hermanos de hábito, fray Vicente Vernedo, muerto en la villa de Potosí en 1619, y fray Juan Macías muerto en Lima en 1645, y la publicación de la historia de la provincia peruana de su orden. No se trataba de una procuraduría de poca monta, pues conseguir del Consejo de Indias las reales cédulas de presentación de las causas de canonización para las autoridades romanas era tarea de considerable manejo político y ardua diplomacia. A esto se sumaba el conseguir las licencias para publicar en la corte papal la hagiografia de Macías y la monumental historia de su orden en el Perú, obra que además recogía la versión más completa de la hagiografia del padre Vernedo, cuya edición limeña databa de $1675 .{ }^{1}$

Ambas empresas editoriales constituirían el frente propagandístico requerido para influir en la lectoría católica europea a favor de estas nuevas causas y, en particular, en la decisión de la romana Congregación de los Santos de acelerar los procesos de canonización. ${ }^{2}$ El padre Meléndez era muy consciente de la importancia de las tareas encomendadas tanto para su orden como para el catolicismo peruano y español, pero, sobre todo, muy consciente de los réditos intelectuales,

1. La hagiografia del padreVicente Vernedo apareció en Lima en 1676 y una versión resumida llegó a las páginas de la crónica dominica Tesoros verdaderos de las Indias. Véase Juan Meléndez, Vida, virtudes, y muerte del venerable siervo de Dios, y penitente padre Fray Vicente Vernedo (Lima: Joseph de Contreras, 1676).

2. Las obras del padre Meléndez publicadas entre su llegada a Madrid, en 1680, y su retorno al Perú, cuatro años más tarde, son: el impreso el Memorial al Rey (1680) y las dos grandes empresas editoriales aparecidas en Roma. Véase Juan Meléndez, Tesoros verdaderos de las Indias. Historia de la Provincia de San Juan Baptista del Perú del orden de Predicadores, 3 tomos (Roma: Imprenta de Nicolás Angel Tinasio, 1681-1682); Juan Meléndez, Vida del venerable siervo de Dios Fray Juan Masías, religioso lego del Orden de Predicadores, hijo de la gran provincia de San Juan Bautista del Perú (Roma: Imprenta de Nicolás Angel Tinasio, 1682). 
sociales e institucionales que el éxito de su procuraduría le rendiría a nivel personal. Había llegado a Roma premunido de suficiente capital monetario y simbólico para acometer dichas empresas, dado que su orden vivía aún a la sombra de la exitosa canonización de Rosa de Santa María de 1671, y el rico cabildo potosino se había comprometido institucional y financieramente con la canonización de fray Vicente Vernedo. El padre Meléndez sabía, sin embargo, de los obstáculos a vencer. El primero era allanar el camino para la causa de sus hermanos de religión y en particular el de la causa de santidad de Vernedo, a quien el cabildo potosino - en flagrante oposición a la normativa vigente - se había adelantado en declarar santo patrono de la villa imperial entre 1663 y $1675 .^{3}$ Lo segundo era la desconfianza que desde el reinado de Felipe IV existía hacia los procuradores indianos, pues, como representantes de corporaciones religiosas y de las ciudades americanas, amparados en su estatus diplomático, por lo general atendían asuntos personales en Madrid y en Roma; circunstancia que podía jugar en contra de su misión. ${ }^{4}$

En estas páginas se revisará el frustrado desempeño de un procurador religioso limeño en la corte papal y su enfrentamiento a una corriente adversa a sus intereses de promoción de la santidad criolla peruana a fines del siglo XVII. Esta circunstancia surge inicialmente de un conflicto personal y devino en el rechazo a la promoción de una causa de santidad y a la manifestación de un sentimiento abiertamente antiamericano de ciertos círculos letrados que estaban vinculados a la legación española, los cuales hicieron del padre Meléndez una víctima de la burla pública y, eventualmente, un fracasado gestor.

3. Urbano VIII emitió disposiciones a fin de regular el proceso de canonización en 1625 y 1634, y centralizar el proceso de declaratoria de la santidad en la curia romana.Véase Bartolomé Bennassar, La monarquía española de los Austrias. Conceptos, poderes y expresiones sociales (Salamanca: Ediciones Universidad de Salamanca, 2006) 134. No se ha encontrado mención a la fecha de declaración de Vernedo como "santo patrono de Potosí", pero por la hagiografia limeña de Meléndez pudo haber sucedido o cuando el obispo de Charcas, fray Gaspar de Villarroel, ordenó la segunda causa sumaria de 1663, y antes de publicarse la hagiografia limeña en 1675, siendo corregidor de la villa imperial el conde de la Granja, D. Antonio de Oviedo y Herrera.Véase Meléndez, "Dedicatoria", Vida, virtudes y muerte.

4. "En mi consejo real de las Indias se han reconocido y experimentado graves inconvenientes de la facilidad con que pasan los religiosos de la orden de Santo Domingo desde las provincias de las Yndias a esa corte romana sin presentar en el consejo las licencias y instrucciones públicas que deven traer y particularmente las actas que se hacen en los capítulos provinciales...y otras proposiciones y nobedades que miran a turbar la paz pública y govierno económico que como patrón me pertenece". Felipe IV pidió se evite la larga estancia de los procuradores "ociosamente" tanto en Madrid como en Roma. Véase "Carta del rey a D. Gaspar de Sobremonte, lugarteniente en Nápoles”, Madrid, 28 de agosto de 1658. MAECE, Madrid, Sección Santa Sede, leg. 116,f. 180r. El documento regio solo confirma lo propuesto por Oscar Mazín, para quien el cargo de procurador en el caso del virreinato peruano tuvo como característica permanente una importante cuota de autonomía. Los procuradores eran agentes que demandaban mayor representación política y autonomía en distintos niveles de la administración virreinal. Oscar Mazín, "Leer la ausencia: las ciudades de Indias y las cortes de Castilla, elementos para su estudio (siglos XVI y XVII)", Historias 84 (2013): 99-110. 
Pese a algunos logros significativos, sobre todo los de orden editorial — que en el largo plazo fueron hitos en la proyección europea de la República de las Letras virreinal peruana- los principales cometidos del padre Meléndez en Roma no tuvieron éxito: Fray Juan Macías tendría que esperar hasta 1837 para ser beatificado y la causa de frayVicenteVernedo fue desestimada por la sagrada congregación romana. Su leyenda de santidad se extinguió como las argentíferas vetas que financiaron su causa a fines del siglo XVII, y su agente, el padre Meléndez, se convirtió en un dominico desacreditado. ¿A qué se debió que el padre Meléndez, quien había llegado a Roma premunido de importantes cometidos, fondos y el endose real, y que en un primer momento fuera bien recibido en importantes círculos intelectuales y sociales, enfrentara hacia el final de su estancia de cuatro años circunstancias tan adversas? Su paso por la regencia del colegio romano de La Minerva, su cátedra de apreciado lector de teología en Nápoles o el endose de algunos contertulios a su obra no evitaron que el procurador fuera motivo de una acre campaña de burla a través de una guerra de sátiras que circuló por Roma y erosionó seriamente los cometidos de su procuraduría. ${ }^{5}$

\section{Un intercambio virulento}

El conjunto de seis poesías satíricas que se considera están en el centro de la campaña de descrédito del padre Meléndez provino de la pluma de un anónimo poeta contemporáneo, quien firmaba con la inicial " $N$ ", autor particularmente duro en el menoscabo de la reputación intelectual de fray Juan Meléndez y de su crónica de la provincia dominica Tesoros verdaderos de las Indias, impresa en Roma en dos volúmenes entre 1681 y $1682 .{ }^{6}$ Las piezas satíricas revelan un gran conocimiento personal del procurador y de las razones de su estancia en la corte papal, así como un considerable prejuicio respecto a las Indias y sus pobladores, y en particular hacia los naturales del Perú, tanto criollos como indios y negros esclavos. En el conjunto de cuidadas sátiras, se deslizan irónicos comentarios sobre la calidad de la educación del clero americano y la importancia de los asuntos que las órdenes

5. "Por parte de fray Juan Meléndez de la orden de Predicadores, Procurador General [...] y especialmente diputado para las causas de beatificación y canonización del siervo de Dios fray Vicente Vernedo de la misma orden, natural del reyno [...] me a suplicado sea servido de recivirla devajo de mi protección ynterponiéndome con Su Santidad para que conceda sus letras remisoriales." "Carta de Carlos II al marqués del Carpio", Madrid, 28 de abril de 1680. Ministerio de Asuntos Exteriores, Unión Europea y Cooperación de España (Madrid), Sección Santa Sede, leg. 158. Sobre la trayectoria romana del padre Meléndez, véase Domingo Angulo, Santa Rosa de Santa María. Estudio bibliográfico (Lima: Sanmartí, 1917) 56-57; María Estela Maeso Fernández señala que Meléndez llegó a Roma a activar la canonización de Santa Rosa, pero ya era santa desde 1671. http://dbe.rah.es/biografias/25688/juan-melendez (25/03/2021).

6. Madrid, Biblioteca Nacional de España, Mss 2100, ff. 64-67. El catálogo publicado de este corpus de poesías satíricas se titula: "Poessías varias manoscriptas compuestas por diferentes autores", Inventario general de manuscritos de la Biblioteca Nacional, t. 6 (Madrid: Ministerio de Educación Nacional, 1962). 
religiosas promovían en las cortes real y pontificia. Sobre todo se revela una gran animadversión respecto al poder económico de estas en auspicio de la santidad - $\mathrm{u}$ otra agenda - indiana. Esto permite plantear la lectura de este conjunto de sátiras como algo más complejo que solo una justa poética entre dos letrados españoles de distinto origen geográfico - Meléndez intentó contestar los ataques sin el brillo de su oponente- en una ciudad de gran sofisticación cultural, acostumbrada a estas justas literarias, sino ver en estos textos, confrontados con el objeto de la procuraduría del padre Meléndez, el enfrentamiento entre dos visiones del mundo: una propia de las élites cortesanas europeas y su concepción de una sociedad aristocrática y monolíticamente jerarquizada y conservadora, opuesta a otra, representada por las élites intelectuales americanas, de raigambre mesocrática, pero más dinámicas y globalizadas.

Este conflicto permite igualmente entender el fracaso indiano en las cortes europeas, no por falta de agencia o recursos americanos, sino como fruto del divorcio de intereses trasatlánticos al interior de la monarquía hispana, que empezó a tomar forma hacia fin del siglo XVII. Se perfilaron así dos modelos sociales y políticos de mayor o menor rigidez, lo que, en el caso indiano, permitió una mayor movilidad social respecto de la sociedad europea, que solo aceptaba la política de la gestión cortesana en manos de los representantes más conspicuos del estamento nobiliario, en un orden social altamente jerárquico. Nótese en el siguiente ejemplo esa visión profundamente negativa de América, su cultura letrada y sus habitantes, que casi anuncia la visión negativa de la Ilustración:

Meléndez soy, que nací

En Lima, y muy mal limada

Tengo una historia, comprada con plata del Potosí:

... Yo y mis libros, en estados
Diversos hemos caydo;
Pues yo, estoy como vendido,
Y ellos, no como comprado.
Proividos son, los cuitados,
Y no por la Inquisición,
Sino por la indiscreción
Que en cada palabra gravo.
Yo me soy ingenio vuestro.

Pero seiscientos cavales cuerpos, a las Indias van;

Y al menos los comprarán

Algunos indios bozales.

Mas si fueren tan fatales,

Que de ellos no saco un real,

Los daré a mi provincial para que se limpie el ravo. 
Yo me soy ingenio bravo

Yo me lo escrivo y yo me lo alavo. ${ }^{7}$

Al margen de descalificar la obra de fray Juan Meléndez O.P., Tesoros verdaderos de las Indias, como producto del dinero, resultado de un pobre esfuerzo intelectual o por ser una ínfima publicación destinada al consumo de una sociedad mayoritariamente analfabeta y supersticiosa, es claro que el encono del crítico poeta " $\mathrm{N}$ " no estuvo basado en el desconocimiento personal del cronista, sino precisamente lo contrario. La opinión sesgada se construyó sobre aspectos reales como la procuraduría de Meléndez y el auspicio potosino a esta, circunstancias que solo podría haber conocido por comunicación del propio autor o de alguien muy cercano a él. ¿Cómo explicar entonces este encono contra el dominico limeño por parte de este personaje en la corte romana? ¿Respondía el sentimiento antiamericano de "N" a una opinión personal únicamente? ¿Era consciente "N" de que la burla pública al procurador y su obra tendrían efecto en los círculos españoles de la corte romana y en la burocracia vaticana misma? ¿Era este avivado descrédito consecuencia de un natural proceso de desgaste de los procuradores españoles en la corte romana? En las páginas siguientes se opondrá la trayectoria personal y profesional del padre Meléndez, su ascenso al interior de su orden y de la sociedad de la Lima virreinal y la evolución de su misión hagiográfica en Madrid y Roma, al perfil de sus posibles adversarios en Roma y a la atmósfera social y política que se vivía en la corte papal. A partir de ello, se proponen unas líneas de reflexión sobre el contraste entre el proceso de formación social del virreinato peruano a fines del siglo XVII, que se manifiesta en la vida y obra de Meléndez, en contraste con el mundo de la comunidad española de Italia en el que vivió el anónimo "N", con el objetivo de comprender mejor el trasfondo del ataque y sus implicancias.

Antes de analizar el enfrentamiento entre las plumas del padre Meléndez y el virulento "N", es importante destacar algunos aspectos del contexto global del imperio español de la década de 1680 para entender mejor el fin del cometido de Meléndez y el impacto de la burla pública en su procuraduría. En el ocaso del reinado de los Austrias, cuando el catolicismo virreinal peruano parecía hallarse en su mejor momento como proyecto cultural y político, la orden de Santo Domingo del Perú se consolidó como la corporación religiosa peruana más importante, destacada en la promoción de candidatos a la santidad. La limeña Rosa de Santa María ya era la primera santa de América desde 1671 y los dominicos del Perú buscaban al menos dos canonizaciones más. Lograr la beatificación de fray Juan Macías y fray Vicente Vernedo era consolidar un modelo de evangelización criolla dominica y poder mostrarle al orbe católico los logros que para la iglesia universal había logrado la provincia peruana de San Juan Evangelista. Para conseguir ese fin, la publicación de las hagiografias y sobre todo la historia institucional dominica en Roma eran empresas cruciales, pues las vitas debían ser leídas en diálogo con

7. BNE, Madrid, Mss. 2100, ff. 99r-100r. 
la historia del desarrollo institucional de la orden. Estos cometidos tenían gran importancia debido a que el catolicismo hispano militante experimentaba cierta ralentización a fines de la era de la confesionalización, luego que la Paz de Westfalia acabara con el ideal de una monarquía universal española y la iglesia criolla americana quedara aislada en su meta de impulsar demandas de representación amparadas en la expansión de un orden confesional bajo el doble liderazgo del trono y el altar. ${ }^{8}$

Varios aspectos de índole institucional —como nombramientos, privilegios, constituciones, fundaciones - concernientes al empoderamiento de la iglesia regular americana y las élites criollas vinculadas a ella, que antaño habían sido gestionados con cierto éxito en Madrid, habían perdido fuerza como formas de promover y posicionar a las élites hispanoamericanas. La santidad, en cambio, era desde la perspectiva peruana un tópico particularmente importante para afirmar los valores confesionales de la monarquía hispana y permitía reposicionar y fortalecer la representación política, la identidad imperial y la cultura global de los súbditos de ultramar. A principios de la década de 1680, el desmantelamiento del sistema de representación de cortes ya no favorecía la libre gestión de los procuradores religiosos americanos y estos habían disminuido en número y en agencia. Los pocos procuradores con asignaciones precisas que llegaron a Madrid y Roma en las últimas décadas del siglo XVII tenían la santidad como primer objetivo para canalizar aspiraciones institucionales y regionales de proyección política, galvanizar voluntades en Europa para la causa del catolicismo global y, sin duda, promover sus propias carreras intelectuales. La santidad como objetivo de una procuraduría criolla podía mover algunas voluntades aún en el ocaso de estos antaño poderosos agentes que habían logrado unir asuntos eclesiásticos y política americana.

\section{Mundos diferentes}

Para comprender el contexto de este conflicto resta ocuparse de la corte pontificia. ¿Qué características tenía el mundo romano a fines del siglo XVII y por qué era importante validar la santidad americana en dicho contexto? La respuesta a esta segunda interrogante es en parte obvia. Desde el reinado pontifical de Urbano VIII (1623-1644) solo era posible formalizar los procesos de canonización ante

8. Sobre la era de la confesionalización, se sigue la propuesta de Heinz Schilling. Después de la segunda mitad del siglo XVII, la política basada en la religión dejó de tener sentido para dar paso a un mundo de alianzas y diplomacia secularizadas; la religión dejó de tener importancia como aliado de las doctrinas de Estado sobre las que se basaban las monarquías modernas. Véase Heinz Schilling, Early Modern European Civilization and Its Political and Cultural Dynamism (Hannover / Londres: University Press of New England, 2008) 82-86. Para entender la naturaleza del sistema de representación a través de las cortes españolas del temprano periodo moderno, véase José Ignacio Fortea Pérez, "An Unbalanced Representation:The Nature and Functions of the Cortes of Castile in the Habsburg Period (1538-1698)", Realities of Representation. State Building in Early Modern Europe and European America, ed. Maija Jansson (Hampshire / Nueva York: Palgrave Macmillan, 2007) 149-169. 
las respectivas instancias de la curia romana: la Sagrada Congregación de Ritos - hoy Sagrada Congregación para las Causas de los Santos-, observar el debido proceso de elevar informaciones y analizar documentos y evidencias, tarea a cargo de los procuradores de las órdenes religiosas a las que pertenecían los candidatos al altar. Estos procesos suponían un permanente desembolso de fondos y, eventualmente, la canalización de estos hacia agentes e intermediarios a fin de agilizarlos. En Roma, los procuradores de órdenes religiosas debían presentarse primero ante la legación española, pues el proceso se iniciaba con la formalidad diplomática de presentarse ante el representante de la Corona. Era la legación española la encargada de presentar a través de su embajador la voluntad del monarca - la gestión en sí- ante el papado.

La influencia y el prestigio español en Roma eran muy importantes y notorios pese a que, a partir de la segunda mitad del siglo XVII, la esfera de influencia del llamado "partido francés" aumentaba y el ocaso de la predominancia española era innegable. A pesar de ello, hubo un breve repunte de la influencia española desde el reinado de Inocencio X (1644-1655) al de Clemente X (1670-1676), y la corte romana todavía podía ser descrita hacia 1680 como una trama de patronazgos políticos en la que el rey de España, sus embajadores, los cardenales a su favor, los miembros de la curia y hasta los santos pertenecientes al imperio español jugaban roles decisivos al influir en opiniones y decisiones al nivel local e imperial, en lo secular y lo eclesiástico. ${ }^{9}$ Precisamente por ello, la vida diaria en la corte romana era la de una tácita guerra entre los principales poderes católicos de Europa y el papa, árbitro indiscutible de ese campo de batalla donde los defensores o detractores de España buscaban influir en las cámaras vaticanas. A este ambiente hay que añadirle la trama de pequeñas intrigas que distinguen los ámbitos cortesanos en general, formados por los varios círculos de poder alrededor del papa y sus favoritos, ricos cardenales y los embajadores. Pajes, secretarios, escribanos y paniguados tenían una voz en las antecámaras de los personajes cuya opinión favorable había que buscar y el descrédito ante ellos determinaba el éxito o el fracaso de cualquier misión y procuraduría. Esa era la ciudad a la que llegó el padre Meléndez con el encargo de fortalecer la misión de la iglesia criolla peruana a través de las causas de santidad dominicas. Allí conocería al influyente "N", quien lo introduciría en la jerárquica y sofisticada corte papal, pero la cercanía inicial entre ambos personajes devendría en enemistad y tal circunstancia determinaría los límites de la misión del fraile limeño.

A diferencia de "N", nacido en la aristocracia española y acostumbrado al brillo y al poder, Meléndez venía de un mundo igualmente jerárquico, pero socialmente más dinámico. El virreinato del Perú, si bien disminuido económicamente, era aún el principal centro de poder en América del Sur a fines del siglo XVII y Lima, el

9. La definición es usada por Thomas James Dandelet para la época del auge español en Roma, que va de mediados del siglo XVI hasta la primera mitad del siglo XVII, pero bien describe el ambiente de fines de siglo.Véase Thomas James Dandelet, Spanish Rome, 1500-1700 (New Haven / Londres:Yale University Press, 2001) 190 y 218. 
centro incuestionable de la región. En un mundo fácilmente controlado desde la esfera de la corte virreinal, los dominicos del Perú se habían consolidado como una fuerza intelectual y religiosa al lado del poder, por su inicial control de la universidad, su presencia en prestigiosas cátedras de escolástica y en el Santo Oficio, y desde 1669 eran aliados naturales de la élite urbana identificada con el primer modelo de santidad criollo. Prominentes figuras intelectuales y económicas estaban ligadas a la orden, como era el caso del millonario doctor Feliciano de Vega y Padilla y sus sobrinos. Pero en la segunda mitad del siglo XVII, la economía urbana limeña había producido una considerable movilidad social y Meléndez reflejaba ese proceso. Su fulgurante carrera en la orden de Santo Domingo explica que se le encargara una procuraduría de tanta importancia política y simbólica para su instituto ante las cortes real y pontificia. Tal encargo también evidencia el ascenso del padre Meléndez al interior del ámbito dominico y limeño, y revela un interesante proceso de construcción del poder colonial. Los estudios sobre conciencia criolla al interior de las órdenes religiosas ofrecen las claves del proceso de consolidación de las corporaciones religiosas peruanas en el siglo XVII como grupo social a través de la cooptación de canteras institucionales por parte de los principales linajes beneméritos de Lima en búsqueda de reconocimiento y cuotas de representación. Desde esas trincheras institucionales se produjo una visión historiográfica interesada en fortalecer la alianza entre la iglesia criolla y la Corona, para afirmar así la precedencia del virreinato peruano y sus élites al interior de la monarquía compuesta. ${ }^{10}$ Desde que las órdenes empezaron a promover estas historias de virtud y santidad en el Perú en la década de 1610, era claro también que sus autores, miembros de distinguidas familias de la ciudad de Los Reyes y estratégicamente ubicados en la iglesia regular, buscaban afirmar derechos de prelación y elevarse en la burocracia religiosa del imperio, con lo que consolidaban su rol como intelectuales. Cuando estos autores fueron investidos del rango de procuradores de sus órdenes o de su ciudad, cruzaron el Atlántico para impulsar también agendas de interés institucional, estamentales y hasta de índole personal.

Pero en ese modelo no se ubica necesariamente el cronista-procurador, pues, si bien representaba a la empoderada orden de los dominicos, también era parte de un sector social nuevo en ascenso en Lima. A diferencia de varios de sus predecesores y hermanos de hábito, Meléndez no provenía de linaje benemérito, sino de

10. Sobre identidad y el discurso criollo, véase Bernard Lavallé, Las promesas ambiguas. Ensayos sobre el criollismo colonial en los Andes (Lima: Pontificia Universidad Católica del Perú / Instituto RivaAgüero, 1993); Bernard Lavallé, ed., Máscaras, tretas y rodeos del discurso colonial en los Andes (Lima: Instituto Francés de Estudios Andinos / Instituto Riva-Agüero / Pontificia Universidad Católica del Perú, 2005). Sobre historiografia religiosa, véase Carlos Gálvez Peña, "Historias religiosas como narrativas imperiales en el Perú del siglo XVII", Historia de las literaturas en el Perú, vol. 2, coords. Raquel Chang-Rodríguez y Carlos García-Bedoya M. (Lima: Fondo Editorial Pontificia Universidad Católica del Perú / Casa de la Literatura / Ministerio de Educación del Perú, 2017). Sobre empoderamiento criollo y la conexión con la orden de Santo Domingo, véase Carlos Gálvez Peña, "Obispo, financista y político: el doctor don Feliciano de Vega y Padilla (15801641)", Histórica 36.1 (2012): 97-133. 
un modesto y esforzado sector inmigrante, que rápidamente se posicionó económicamente en la ciudad, al mismo tiempo que la segunda generación lo hacía institucionalmente en la orden, a pesar de sus humildes orígenes. Para hombres como el padre Juan Meléndez, las posibilidades de ascenso social de Lima en la segunda mitad del siglo XVII solo podían ser ofrecidas por la solidez de las corporaciones religiosas, pero también por una sociedad dinámica, donde las fronteras de clase y estamento eran cada vez más fluidas y la patriótica defensa del catolicismo militante español constituía una carta de ciudadanía suficientemente sólida. La evidencia de estos cambios en el virreinato peruano se advierte en el contraste ofrecido entre el perfil de los procuradores dominicos del siglo XVII. En 1650, la orden envió a Madrid a fray Antonio González de Acuña, autor de un sesudo memorial de corte histórico y miembro de una prominente familia limeña, perfil que caracteriza a las autoridades dominicas más destacadas de la primera mitad del siglo, como también fue el caso de fray Cipriano de Medina y Vega, sobrino y administrador del millonario patrimonio legado por el obispo Vega ya mencionado. En 1670, regresaría como exitoso impulsor de la canonización de Rosa de Santa María. ${ }^{11}$

Las cosas empezaron a cambiar en la década de 1660 y hacia 1678 se advierte un viraje social en la elección del prometedor Meléndez para la procuraduría más importante de la orden. ${ }^{12}$ Fray Juan era el hijo de inmigrantes peninsulares pobres, nacido en Los Reyes en 1632. El padre de Meléndez fue un talabartero analfabeto que luego de muchos años de trabajo pudo hacer cierta fortuna en Lima y el Callao, ciudades en las que abrió tiendas de venta de monturas y otros artículos de cuero. Los registros notariales evidencian que Rodrigo Meléndez sabía hacer negocios, pues, pese a ser analfabeto y firmar con una " $\mathrm{X}$ ", tuvo a su cargo importantes transacciones y llegó a tener hasta dos establecimientos de su ramo en la ciudad. No fue una carrera exenta de vicisitudes y, cuando fue perseguido por los deudores, Rodrigo se refugió en el asilo del convento dominico, y selló la alianza entre su descendencia y la orden. La madre del cronista, Catalina Rodríguez de Guzmán, al parecer tenía mayor instrucción, pero acaso un origen converso. La pareja logró el éxito económico y consolidó un patrimonio del que vivieron las

11. Fray Antonio de González de Acuña, Informe a Nuestro Padre General de la Orden de Predicadores, Fray Joan Baptista de Marinis, le ofrece el presentado Fray Antonio González de Acuña, catedrático de Prima de Moral, Procurador de la Real Universidad de los Reyes, definidor de la Provincia de San Joan Baptista del Perú (Madrid: [s.e.], 1659). Sobre su gestión al frente de la canonización de Rosa de Santa María, véase Ybeth Arias Cuba, "Integración de un sistema devocional indiano en la Monarquía Hispana. El culto de santa Rosa de Santa María en las ciudades de Lima y México, 1668-1737" (Tesis de doctorado en Historia, El Colegio de México, 2019).

12. Meléndez fue electo procurador general de su provincia en el capítulo de 1677. Dicha elección fue consecuencia de una larga lista de logros institucionales, pues, según Angulo, fray Juan hizo carrera en la orden de Santo Domingo como maestro y presentado, fue regente de estudio en el Cuzco y en el colegio de Santo Tomás de Lima, prior del convento de Trujillo y vicario provincial de su orden en el arzobispado de Lima y en los obispados del Cuzco, Arequipa, Huamanga y Panamá a lo largo de la década de 1660, además de director de seminarios y colegios de su orden. Angulo 56-57. 
cuatro hijas solteras, en un ambiente de piedad y comodidad. Otros tres hijos del iletrado talabartero profesarían en la orden dominica: Juan, Rodrigo y Diego, y un cuarto hijo, Andrés, seguiría la carrera eclesiástica secular. ${ }^{13}$ A los 25 años, fray Juan Meléndez ya era lector de teología en Lima, y entre 1667 y 1677, ocuparía cargos de rector y prior de los conventos de su orden en Cuzco, Trujillo, Huamanga y Panamá. En 1679, a los 47 años, coronó su ascenso con su elección como viceprior de su provincia y procurador de la misma para viajar a Europa a ocuparse de los asuntos ya señalados. ${ }^{14}$ Adicionalmente, la trayectoria de Meléndez como hagiógrafo y cronista de su orden se había iniciado en 1669 con la publicación de Festiva pompa, culto religioso, veneración reverente, fiesta, aclamación y aplauso a la feliz beatificación de la bienaventurada virgen Rosa de Santa María, en 1671, relación de las fiestas con que la orgullosa Lima celebró su primera santa. A esta relación le siguió la publicación, también en Lima, de Vida, virtudes y muerte del venerable padre y penitente siervo de Dios, fray Vicente Vernedo, en 1675. Con una carrera intelectual consolidada y un perfil social debidamente mejorado, el ambicioso fraile se embarcó para España en 1679 con destino a la corte papal. ${ }^{15}$

Pese a su fama de eficiencia, su determinación y una buena bolsa, la procuraduría de Meléndez se presentaba compleja. Sorteó la primera valla en Madrid, al obtener del rey la real cédula de presentación de la causa de santidad de fray Vicente Vernedo en Roma, donde tenía que convencer a la corte papal de los méritos de ese oscuro dominico muerto en Potosí, tarea ya no tan sencilla. En lo personal, el fraile criollo confiaba en que su éxito promovería su talento y letras. Esto se debía lograr con la difusión de sus hagiografias de Vernedo y Macías, pero, sobre todo, con la publicación de la crónica dominica, obra destinada a cimentar la virtud, el dinamismo y la riqueza del catolicismo urbano peruano y presentar a la ciudad de Lima como la república cristiana ideal, hito de la geografia católica global y fruto americano del plan de redención. Lima no solo sería considerada bastión de piedad y santidad de sus habitantes más encumbrados, sino una ciudad donde los sectores populares — indios y esclavos - al participar de un excelso modelo de evangelización, habían adquirido la ciudadanía cultural hispana. La solidez y diversidad de la religiosidad de Lima hacían de ella la civitas catholica hispana, donde todas las "naciones" se unían en un modelo confesional justificatorio de la donación pontificia de las Indias a la Corona de Castilla, prueba irrefutable de la legitimidad de la monarchia universalis española.

13. José de la Riva-Agüero y Osma, La historia en el Perú (Lima: Pontificia Universidad Católica del Perú, 1965) 256.

14. Carlos Gálvez Peña, "Writing History to Reform the Empire. Religious Chroniclers in Seventeenth-Century Peru" (Tesis de doctorado en Filosofia, Columbia University in the City of New York, 2012).

15. Meléndez salió del Callao por encargo del prior el 2 de noviembre de 1677 y llegó a Cádiz el 26 de agosto de 1679, tras un azaroso viaje. Alberto Tauro del Pino, Diccionario enciclopédico del Perú, t. 4 (Lima: Editorial Juan Mejía Baca, 1975) 1312. 
En este esquema jugaban un rol crucial la obra hagiográfica del padre Meléndez y su visión de la misión de la provincia dominica del Perú, en particular el esfuerzo editorial de los Tesoros verdaderos de las Indias, crónica de su orden con la que se cerró el ciclo historiográfico religioso del siglo XVII. Tres magníficos tomos evidenciaron la importancia que le había otorgado la orden a una historia llamada a ser divulgada en la corte papal, en la que los modelos de santidad peruanos promovidos por los dominicos ponían de relieve la piedad urbana limeña y el éxito de la colonización española sobre culturas tan diversas, ahora hermanadas en una ciudadanía católica española. Los candidatos a santidad dominicos lo eran por su aporte a la consolidación del orden colonial y al fortalecimiento de lazos interraciales e interculturales, en suma, a la cohesión del modelo imperial español. Para convencer a Roma de esto, en un contexto no necesariamente proespañol, el padre Meléndez tenía que hilar fino. No era dificil elaborar las virtudes de fray Juan Macías, quien tenía tras de sí una larga historia de caridad para con la población indígena del pueblo de La Magdalena de Lima, lo que podía verse como mérito de la evangelización rural. Pero fray Vicente Vernedo, por el contrario, tenía un récord evangelizador poco claro en Potosí, o al menos el procurador no se interesó en elaborarlo, lo cual pudo haber hecho mucho por su causa en un momento en que los logros evangelizadores ganaban adeptos en la Sagrada Congregación de Ritos. Hay que considerar que tan solo cinco años antes de la llegada de Meléndez a Roma, Francisco Solano había sido elevado a los altares a partir de un historial de evangelización indígena en Tucumán y Paraguay, y cuatro años después, en 1679, Toribio de Mogrovejo llegaría a los altares, promovido como santo misionero y evangelizador de la población nativa. ${ }^{16}$ Por el contrario, Meléndez enfatizó en su obra hagiográfica el culto criollo y urbano a Vicente Vernedo en Potosí y Lima, que para el Perú de fines del siglo XVII ciertamente tenía importancia como fenómeno cohesionador de ciudades multiétnicas, más no necesariamente generaba entusiasmo en Roma. ${ }^{17}$

16. En Roma, Meléndez conoció al sevillano Francisco de Montalvo, procurador del cabildo de la catedral de Lima para la causa del arzobispo Toribio Alfonso de Mogrovejo, quien completaba en esos años la hagiografia del santo arzobispo. Francisco Antonio de Montalvo, El sol del nuevo mundo: ideado y compuesto en las esclarecidas operaciones del bienaventurado Toribio arzobispo de Lima (Roma: Imprenta de Angel Bernavó, 1683). En opinión de Riva-Agüero y Osma, Meléndez copió, con autorización de Montalvo, su descripción de Lima para su crónica. Riva-Agüero y Osma 256.

17. Hay en la información sumaria una breve referencia a las misiones "entre ynfieles", pero los testigos sobre los "milagros" del padre Vernedo fueron básicamente las hermanas solteras de la familia del procurador y sus esclavos domésticos. "Información sumaria hecha a pedimento del procurador de la orden de Predicadores en orden a los milagros que la divina magestad de Dios nuestro señor obró por la intercessión de las reliquias de su venerable siervo de Dios el padre maestro Fray Vicente Vernedo. Juez, el señor don Agustín Negrón de Luna, canónigo desta Santa Iglesia Metropolitana, por comisión del Illmo. Señor arçobispo Melchor Liñán y Cisneros", Negrón de Luna, Agustín de, Lima, abril-mayo de 1678, Archivo Arzobispal de Lima, f. 48v. Sobre los sueños de una de las esclavas de las hermanas Meléndez con Vernedo, véase Carlos Gálvez Peña, "Sueños, profecías, visiones y política en las crónicas limeñas del siglo XVII", Los sueños en 
Largas páginas de los Tesoros verdaderos de las Indias serán dedicadas a "milagros" obtenidos en nombre de Vernedo, pero que curiosamente tenían a la familia del cronista como protagonista. Dado que se trata de largos episodios, aquí se resumirán solo dos que tienen como contexto la casa familiar del cronista, uno de ellos, además, el centro de las agudas críticas de "N". El primero trata del sueño de la niña esclava Rosita, hija de la cocinera y criada de las devotas hermanas Meléndez. Afectada de altas fiebres, la niña esclava había sido encomendada por sus piadosas amas al "santo" y luego de soñar con él —amante de la niñez, según la información de 1678-, la joven esclava amaneció curada, y luego pudo identificar en un grabado a Vernedo como el buen hombre de sus sueños. El segundo episodio es bastante más pintoresco: Juan Popo, negro bozal en la casa de las Meléndez, criaba un pollo con particular cuidado. Un día, Mariana, la esclava cocinera, descubrió al pollo ahogado en el fondo de una tinaja y, al temer junto a sus piadosas amas la reacción violenta del esclavo, encomendaron al ave (y a ellas mismas) a la intercesión de Vernedo para que calmase al esclavo bozal y, milagrosamente, el pollo cobró vida. Al enterarse del prodigio, Juan Popo, abrazó entusiastamente su nueva religión y se declaró fervoroso devoto del "santo". La paradoja del padre Meléndez en Roma era lograr que su particular visión de la santidad popular de la población criolla y negra de Lima lograra arraigo en la corte papal. Posicionarse él y a su mesocrática familia - y a la población negra esclava - al centro de los episodios milagreros deVernedo le pudo haber significado réditos locales, pero no necesariamente el mismo resultado en Roma, donde la leyenda de santidad de Vernedo fue motivo de burla, no solo por ser Roma una ciudad racial y culturalmente menos diversa que Lima, sino porque promover la circulación de estampas con imágenes de Vernedo, como la que reconoció la esclava Rosita al despertar de su enfermedad, contravenía disposiciones vaticanas. ${ }^{18}$

\section{Pugnas cortesanas}

Con ese particular bagaje intelectual y abogando por un catolicismo multiétnico, llegó a Roma el padre Meléndez y estableció contacto con el secretario de la legación española, don Juan Vélez de León (1655-1736), joven “gentilhombre y

la cultura iberoamericana (siglos XVI-XVIII), eds. Sonia V. Rose y otros (Sevilla: Consejo Superior de Investigaciones Científicas, 2011) 313-342.

18. En 1619, Lima tenía 29,500 habitantes. De estos, casi 12,000 eran negros y mulatos, más de mil eran indios y alrededor de 1,400 eran mestizos. Emilio Lissón, La Iglesia de España en el Perú, t. 5 (Sevilla: [s.e.], 1946) 251. A fines del siglo XVII, la piedad negra en Lima había ganado mucha credibilidad y eran comunes los testimonios de devotos esclavos. En el Proceso de canonización de Santo Toribio (1685) declaró como testigo principal a Nicolasa Bullones, negra libre y ama de leche, "hija de Antonio y de Victoria Angola", de 38 años de edad. Nicolasa servía en la casa del capitán don Antonio de Iturrisara y doña Leonor Fernández de Córdoba, del antiguo linaje de los encomenderos de Huancabamba de Piura, y padres de Bernardo de la Soledad Iturrisarra, de dos años, quien por intercesión del "santo" obispo se había curado de unas flemas que le "cubrían el corazón”. MAECE, Madrid, leg. 159, ff. 155v y 274r. 
secretario de cámara y de zifra” de don Gaspar de Haro y Guzmán, marqués del Carpio y Heliche, embajador y más tarde también virrey de Nápoles, conocido hombre de refinada cultura y coleccionista de arte. ${ }^{19}$ La relación entre el secretario de la embajada y el procurador limeño, inicialmente amistosa, pese a la diferencia de edad, se puede explicar por la fama deVélez de León como el hombre que facilitaba el apoyo de la legación a cambio de una comisión. Acaso se debiera a una generosa “donación” de Meléndez el que un elogioso poema del secretario prologara el primer volumen de los Tesoros verdaderos de las Indias en 1681. Para Meléndez, entrar al refinado círculo del embajador español y grande de España no solo era una necesidad de su procuraduría, sino que coronaba las ambiciones sociales del humilde hijo del talabartero. Si la inicial amistad entre Vélez de León y Meléndez era utilitaria, la plata potosina ciertamente ayudó. El procurador frecuentó también en el entorno de la legación, al canciller Sebastián de Villareal y Gamboa, maestro de cámara del embajador, quien igualmente colaboró con un poema para prologar el segundo tomo de la referida crónica dominica. Los beneficios del padre Meléndez eran obvios: estas relaciones predisponían a favor de su causa la voluntad del marqués del Carpio y, a través de él, al colegio de cardenales y a otros círculos de influencia romana. Los beneficios de los criados del marqués no eran desdeñables, no solo porque cobraban sus servicios, sino que su pluma se hacía conocida. Adicionalmente, obtenían para el marqués del Carpio obvios beneficios monetarios.

Vélez de León y Villarreal eran las llaves de acceso al poder del marqués del Carpio y sus virtudes oratorias, sus maneras cortesanas, sus buenas letras y buen gusto coadyuvaban al brillo del príncipe al que servían y al éxito de la gestión de

19. Rosa López Torrijos, "El coleccionismo en la época de Velázquez: el marqués de Heliche”, Velázquez y el arte de su tiempo. V Jornadas de Arte (Madrid: Consejo Superior de Investigaciones Científicas / Editorial Alpuerto, 1991) 27-36. Vélez de León nació el 25 de junio de 1655 en Madrid y allí murió el 11 de diciembre de 1736. Entre 1668 y 1691 desempeñó varios cargos públicos: fue secretario del Gobierno de Milán, estuvo en las embajadas de Venecia, Francia y Alemania; fue secretario del Marqués del Carpio en Milán, Roma y Nápoles, ciudad donde fue ministro de justicia y secretario de la Junta de Expedientes. En Italia desarrolló gran actividad intelectual como secretario de la Real Academia en Nápoles y miembro de la academia de la reina Cristina de Suecia en Roma. A su regreso a Madrid, en 1691, pasó el tiempo "entregado a gozar de su buena librería" y al servicio del duque de Medinaceli.Véase Fernando Plata Parga, "Don Juan Vélez de León, refundidor de Quevedo (a propósito del romance 'Don Repollo y doña Berza')", La Perinola, Revista de Investigación Quevediana 8 (2004): 343-357. La fama de Vélez de León también alcanzó la traducción. Según Juan Isidro Fajardo, escritor madrileño y miembro de la Real Academia Española, Carlos II pidió al virrey de Nápoles, el marqués del Carpio, poder leer las obras de Maquiavelo y "que con gran secreto y confiança las hiziese traducir e se las embiase”. El marqués encomendó las traducciones a Vélez de León, su secretario, quien en 1721 entregó una copia del manuscrito a Fajardo.Vélez de León desarrolló importante labor pública y también cultural en diferentes ciudades de Italia, como burócrata y autor. María Begoña Arbulu Barturen, "La fortuna de Maquiavelo en España: las primeras traducciones manuscritas y editadas de Il principe", Ingenium. Revista de Historia del Pensamiento Moderno 7 (2013): 11, doi: 10.5209/ rev_INGE.2013.v7.44065. 
Meléndez. ${ }^{20}$ Los altos burócratas de la legación española en Roma eran los encargados de colectar información sensible y donativos para la gestión del embajadormarqués, cuya misión era aceitar la maquinaria de la curia romana a favor de las causas españolas, pero también era conocido por su gusto, por un ostentoso estilo de vida y su selecto coleccionismo. En todo caso,Villareal yVélez de León leyeron el manuscrito de la crónica de Meléndez y el segundo tomo del primer volumen salió de la imprenta en 1681 con sonetos celebratorios de ambos. No hay elementos para conocer mayormente el talento del canciller Villareal, pero otra cosa es el caso de don Juan Vélez de León, consumado poeta al servicio "de las musas y de Mercurio", es decir, al arte y a administrar la bolsa del marqués (sin que eso supusiera perjuicio de la suya propia). ${ }^{21}$ Vélez de León compuso pequeñas obras por vocación propia y por encargo del marqués; luego, en Nápoles, se dedicaría a escribir comedias de estilo quevedesco. A su carrera de funcionario diplomático en varias embajadas europeas hay que sumarle el ser contertulio de la exilada reina Cristina de Suecia y también se le conoce una traducción de Maquiavelo encargada por Carlos II. Pasó sus últimos días en Madrid, ocupado en su biblioteca personal, probablemente adquirida durante sus años en Italia.

Fue el poema laudatorio de Vélez de León en el primer volumen de la crónica dominica del padre Meléndez el que hizo posible identificar, también provenientes de la pluma del secretario, el conjunto de poesías anónimas en la colección de manuscritos de la sala Cervantes de la Biblioteca Nacional de Madrid. En una primera revisión de estos poemas se constató que uno de ellos era idéntico a aquel firmado porVélez de León en 1681 y así fue posible concluir que en efecto era fray Juan Meléndez el objeto de las burlas de los siete sonetos restantes del conjunto, firmados por el anónimo y virulento "N". El cotejo del estilo y el tema hicieron posible comprobar que el conjunto de sátiras poéticas no podía ser de autoría de otro poeta más que el "secretario de cifra" del marqués del Carpio. Aquí el poema laudatorio publicado en 1681, a la letra idéntico a aquel identificado en el conjunto de manuscritos de Madrid:

\author{
A la Historia que intituló Thesoros Verdaderos de las Indias \\ y escrivió en tres tomos el Padre Maestro Meléndez \\ Vistió naturaleza, al tigre, al toro \\ De piel, de pluma al ave, al pez de escama; \\ A tí de un vivo ingenio, que derrama \\ Por fértil vena, celestial thesoro.
}

Entre las nueve hermanas con decoro

20. Sobre la función de los secretarios en el temprano periodo moderno, véase Salvatore S. Nigro, "The Secretary", Baroque Personae, ed. Rosario Villari (Chicago / Londres: The University of Chicago Press, 1995) 82-99.

21. Nigro $88-89$. 
Oigo admirar el eco de tu fama

Nuebo mezenas, que a lo [h] eroico inflama

Sacro assumpto, tu docta pluma de oro.

Humille Potosí su rica frente

Al mineral precioso de tu Historia

Meléndez claro y ríndate tributos

Y pues los das al cielo reberente,

Dezir podrás, a impulsos de tu Gloria

Más que la plata y oro son mis frutos. ${ }^{22}$

Si la amistad inicial entre el procurador y el secretario supuso cierta cercanía y hasta emulación —al menos entre 1681 y 1682 - ¿qué fue lo que sucedió para que el primer elogioso poema se trocara en cinco venenosas sátiras? En parte la clave viene en otro poema del corpus de la Biblioteca Nacional de Madrid que describe un almuerzo organizado en la campiña romana porVélez de León y en el que Meléndez se habría negado a probar un sabroso salame o mortadela romana, ofendiendo al gentilhombre y enfrascándose ambos en una acre discusión. Si este incidente sucedió de manera natural, o si se trataba de un intento premeditado para humillar públicamente al ufano dominico, no se sabe. Hasta pudo ser la altiva respuesta del despechado secretario al no poder obtener más dinero del cronista o haberle increpado este último la ineficaz gestión de la embajada en la promoción de la causa de Vernedo. En todo caso, el cruel poema no solo confrontó a fray Juan con sus humildes orígenes, sino que hasta generó sospechas sobre su posible origen converso. Las pullas durante la recepción debieron haber sido varias $-\mathrm{y}$ acaso no pocos los insultos de Meléndez-, pues Vélez de León amenazó con la burla pública:

Hallábase en campaña $\mathrm{N}$

y bínole a visitar con otros amigos

el Rvmo. Padre Maestro Meléndez,

pidió de merendar y entre otras cossas que se le sirvieron

fue una mortadela de Bolonia, bien sazonada,

22. BNE, Madrid, Mss. 2100, f. 94v. Los poemas están enumerados así: número 64: "A la historia que intituló: Tesoros verdaderos de las Indias y escribió el P. Maestro Meléndez. Soneto:Vistió naturaleza al tigre, al toro", f. 95 v; número 65: "Hallábase en campaña N. y vínole a visitar con otros amigos el P. Maestro Meléndez, pidió de merendar, y le dieron mortatela de Bolonia, hizo muchos ascos el Rmo. y no la quiso comer. Amenazósele por este desaire con un soneto, y él envio éste: Porque a un chorizo le perdí el respeto", f. 96; número 66: "Viendo N. la ingratitud y necedad con que se portaba el Rmo. Meléndez, le fulminó con los qué se siguen este soneto: Pudiera disparar como trabuco", f. 96 v; número 67: "Otros sonetos y versos al mismo: Deseó un maestro hacerse licenciado", f. 97. El número 64 es el que se reproduce íntegro en la crónica de Meléndez de 1681. 
y no extraño manjar en campaña.

Hizo muchos ascos el Rvmo.

Y no la quiso comer,

amenazósele por este desaire con un soneto,

a que el calló, y al día siguiente

le embió a $\mathrm{N}$ con uno de los mismos amigos deste. ${ }^{23}$

El ofendido padre Meléndez contestó a la amenaza y burlas de Vélez de León con un soneto que hizo llegar al propio secretario al poco tiempo del incidente. Para ese momento era claro que la relación entre el procurador y la legación española era de abierta confrontación y cabe preguntarse si el embajador estaba informado de esta querella. Si bien de Meléndez no hay más que un soneto, su tono no es precisamente cordial y en el mundo de las apariencias cortesanas de la corte papal, el penúltimo verso, donde menciona el "linaje de gatos", pudo haber sido motivo de grave ofensa por aludir a un origen que, si bien era castizamente madrileño, estaba ávido por la promoción social, era amante del dinero (en referencia al talego) e incluso carecía de hombría (lo que no hubiera sido de extrañar en un cortesano):

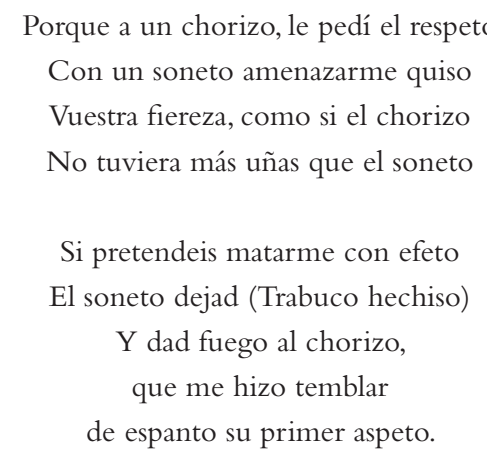

Pero si al fuego le poneis agora

Viéndole assado o frito entre dos platos,

Que dejaré el temor no tiene duda:

Verle crudo, y tan crudo, eso me assora

Que como mi linaje no es de gatos

Nunca probé saynete en carne cruda..$^{24}$

\section{BNE, Madrid, Mss. 2100, f. 96 r.}

24. BNE, Madrid, Mss. 2100, f. 96v. Por "linaje de gatos", Meléndez pudo haber aludido a varias cosas: el ser natural de Madrid, escalador social y hasta amante de la vida nocturna y sus desórdenes. Vélez de León era madrileño y al parecer también era proclive a las tentaciones mundanas. Una acepción de "gato" se refiere al talego usado para echar dinero. Hay que considerar que Vélez 
La respuesta del orgulloso secretario no se hizo esperar y arremetió contra todo aquello de lo que el procurador se ufanaba en un solo verso sobre su origen americano y su valía intelectual: "apodos no entiendo de Morlaco (tonto o ignorante)". De allí en adelante la lluvia de epítetos es intermitente. Meléndez será descrito como "caco" (ladrón sutil), "mamaluco" (necio, tonto), varias alusiones de naturaleza animal (mico) y "arrendajo" (pájaro imitador), con énfasis en las menguadas calidades intelectuales del padre maestro y su tendencia a la copia y falta de originalidad en el uso de las bellas letras y la retórica:

Viendo $\mathrm{N}$ la ingratitud y nezedad con que se portaba el Rvmo. Meléndez le fulminó con los que se siguen:

Soneto M

Pudiera disparar como Trabuco

Si hiziera caso de un poeta caco;

Mas por que no juzgueis que soy maniaco

Os hago este soneto: mamaluco

Pensais que yo he nacido en Pernambuco

Y que apodos no entiendo de Morlaco?....

Regente sois maestro, Pero Mico....

De Persio y Juvenal os falta el pico,

Apolo en vuestros versos se disipe

Pues de sus musas soys el arrendajo. ${ }^{25}$

Al mesmo

Soneto M.

Desseó un maestro hazerse lizenziado

En la poesía, y porque dijo, quiso,

A hechizo, hizo, y chorizo; fue preciso,

Que hizieras eses las zetas, el menguado.

De bachiller quedó bien graduado;

de León era el recaudador del marqués del Carpio y acaso Meléndez quería dar a entender que la llave de la embajada española pasaba por los pagos recibidos por el secretario. Otra acepción de la época se refiere "al afeite femenino" (darse una mano de gato), lo que pondría en duda la virilidad del secretario y aludiría al gusto de Vélez de León por el adorno. Véase Diccionario de Autoridades, t. 1 (Madrid: Real Academia Española, 1726); Diccionario de Autoridades, t. 4 (Madrid: Real Academia Española, 1734)). https://webfrl.rae.es/DA.html (25/03/2021).

25. BNE, Madrid, Mss. 2100, f. 97r. 
Pues jamás conzedieron tal permiso

Las españolas mussas, que conciso,

Y estrecho claustro siempre han observado.

....Comiste en el pesebre del pegaso,

Sin bever en la fuente de las Musas. ${ }^{26}$

Puesta en duda la capacidad intelectual y la formación del procurador, a Vélez de León solo le queda burlarse de la obra producida y en particular de la crónica dominica Tesoros verdaderos de las Indias. El hecho de que se aluda a los tres volúmenes permite fechar al menos cinco de los poemas, y hasta el incidente de la mortadela, en 1682, año en el que se imprimió el último volumen en la prensa de Angelo Tinasio en Roma. Este poema, con el que se busca completar el enfrentamiento entre ambos personajes, es una crítica feroz a la crónica dominica y sus pretensiones de ser una historia religiosa. Al final del poema, Vélez de León alude específicamente al milagro del pollo resucitado, propiedad del esclavo aguatero en la casa de las hermanas Meléndez, y hace mofa del argumento para pedir una canonización. Si estos poemas circularon en Roma, lo que es muy probable dada la pertenencia de Vélez de León a varios círculos letrados, debieron haber tenido un impacto negativo en la procuraduría del padre Meléndez y sobre todo en el fracaso de la causa de santidad de fray Vicente Vernedo. Aquí el último ejemplo de la virulenta poesía satírica de Vélez de León:

Al mesmo. Soneto M.

Una bestia de las Indias, en casi un día

Tres monstruos nos parió, con mil a gatas

Sonetos monos, llenos bien de patas

Juanetes, callos y pedantería.

Esta, eres tú, fray Juan; que quién podías

Darnos las nezedades tan baratas?

Pobre de la regencia, si la tratas

Como sueles la historia, y la poesia!

Tienes talentos, pero en los talegos:

Tienes caveza, pero sin meollos:

Pluma también, pero de grajos finos.

Deja pues ia de hazer versos tan legos,

Y escrive solo historias de los pollos, 
Que te alaben, y compren los pollinos.

$$
\begin{aligned}
& \text { Adviertese, que este penúltimo verso, es alu } \\
& \text { Sivo a un quento ridículo de cierto mi } \\
& \text { Lagros de pollos, que introduze en lo más } \\
& \text { serio de su historia. }{ }^{27}
\end{aligned}
$$

\section{Consideraciones finales: alianzas criollas}

Una vez fracasada la causa de Vernedo, fray Juan Meléndez pudo imprimir en 1682 la hagiografía de fray Juan Macías, el segundo y tercer volumen de la crónica dominica y luego partir hacia Nápoles como lector de teología. La mala prensa causada por la campaña satírica del secretario del embajador fue compensada, sin embargo, por la amistad de Meléndez con importantes personajes por entonces en la corte papal y por el hecho de que al parecer aún contaba con suficientes fondos que ya no pasaban por las manos del marqués del Carpio y sus criados, lo que debe haber sido otro motivo para el encono contra el dominico. Se ha mencionado la cooperación intelectual con el procurador de la causa del arzobispo Mogrovejo en Roma, el licenciado Francisco Antonio de Montalvo y cómo ambos hagiógrafos compartieron información. Pero fue aún más influyente e importante la amistad que trabó Meléndez con el padre general de los dominicos, el novohispano fray Antonio de Monroy e Híjar, O.P. (1634-1715). ${ }^{28}$

La amistad con fray Antonio de Monroy, cuyo grabado ilustra junto con el del autor los volúmenes de la crónica dominica peruana Tesoros verdaderos de las Indias, definiría el sentido de la propuesta historiográfica de Meléndez. Desde el prólogo de la obra quedaba claro que el cronista y su general desconocían el legado lascasiano como línea de interpretación de la evangelización peruana y acusaban a los enemigos de España de ser autores de las falsedades atribuidas a Las Casas, quien no era para su orden una voz crítica del imperialismo hispano, sino solo un falso crítico de origen francés y autor del más pernicioso de los libelos, la Brevísima relación de la destrucción de las Indias. ${ }^{29}$ Meléndez y Monroy acordaron presentar la historia de los dominicos peruanos como opuesta al "falso" Las Casas, pues, al cancelar la voz crítica, los criollos harían suyo el antimaquiavelismo católico, fortalecerían la relación

27. BNE, Madrid, Mss. 2100, f. $98 \mathrm{r}$.

28. Sobre Monroy, véase Oscar Mazín, "Dos mundos, un rey y una patria común: fray Antonio de Monroy e Híjar O.P. (1634-1715)", Cultura y arte de gobernar en espacios y tiempos mexicanos, coords. Nelly Sigaut y Thomas Calvo (Zamora: El Colegio de Michoacán, 2015) 161-191; Adriana Álvarez Sánchez, "De fraile a arzobispo. El novohispano Antonio de Monroy e Híjar (16341715)", Historia Mexicana 69.3 (2020): 951-1021, doi: 10.24201/hm.v69i3.4017.

29. Sobre los debates históricos comunes del siglo XVII, véase Meléndez, "Introducción", Tesoros verdaderos. Monroy había sido electo general de los dominicos con el apoyo del papa, de los dominicos españoles y del embajador, precisamente en oposición al intento francés de controlar las órdenes regulares, pero tuvo que gobernar una orden dividida entre pro-españoles y profranceses. Álvarez Sánchez 982. 
entre trono y altar — crucial para el confesionalismo indiano de la segunda mitad del XVII - y legitimarían la santidad urbana virreinal, ancla de ese confesionalismo y de la identidad de esos sectores urbanos consolidados (Monroy) y sobre todo ascendentes (Meléndez). ${ }^{30}$ En la pluma histórica y hagiográfica de fray Juan, la posesión del Nuevo Mundo por Castilla había sido legitimada con la evangelización pero perfeccionada con la santidad americana. Con los Tesoros verdaderos de las Indias, la historiografía religiosa peruana pelearía la última batalla de la conquista española de América al justificar la soberanía castellana en la trascendencia y el universalismo de su legado religioso, no en la conquista del imperio inca o la nobleza y el valor de los beneméritos. Por ello, la crónica debía dialogar con las hagiografias de los santos dominicos peruanos y para tal revisionismo, Las Casas debía ser apócrifo. La hagiografía criolla como poderoso género de argumentación histórica a favor de la identidad criolla unió a los dos frailes criollos. ${ }^{31}$

Pese a la diferencia social, Monroy se convirtió en el protector del advenedizo Meléndez y acaso hasta lo protegió del descrédito urdido desde la legación española. Ambos criollos eventualmente caerían en desgracia frente al marqués del Carpio, quien acusó al novohispano de no poder controlar las facciones dentro de la orden dominica luego de su elección como general en $1677 .{ }^{32}$ Cuando en 1680 llegó Meléndez a Roma, fray Antonio no solo encontró un interlocutor, sino la posibilidad de que otro criollo asumiera la vicaría general de la orden dado que consideraba renunciar a su cargo, lo que el rey no aceptó. ${ }^{33}$ En ese contexto, con el partido francés en rebeldía y las acusaciones de ineficiencia del embajador, se produjo el intercambio de sátiras entre Vélez de León y Meléndez. Solo el apoyo de Monroy explica que Meléndez ejerciera otros encargos de su orden y terminara sus proyectos editoriales antes de regresar al Perú. Pero no cabe duda de que la campaña de descrédito de Vélez de León a la obra y personalidad del cronista contribuyó al fracaso de la beatificación de Vernedo. El duelo de plumas podría quedar en la anécdota, pero revela los retos de intelectuales criollos como Meléndez, quienes, al impulsar una compleja agenda de identidad y representación política, apuntaron a relanzar el proyecto colonial a través de la santidad criolla en el centro del orbe católico. Llegar a Roma en el ocaso del reinado de Carlos II

30. El antimaquiavelismo como doctrina de Estado y en particular el uso del providencialismo pragmático detrás de esta doctrina es definido por Robert Bireley como el don de las victorias dado por Dios a los príncipes y pueblos que lo servían leal y justamente a través de milagrosas y directas intervenciones en la historia o de una hábil guía de las causas naturales o secundarias. Robert Bireley, The Refashioning of Catholicism, 1450-1700 (Washington: Catholic University of America Press, 1999) 182. Sobre el uso del antimaquiavelismo en la historiografia religiosa del siglo XVII peruano, véase Gálvez Peña, "Historias religiosas".

31. Sobre la promoción de la identidad criolla a través del culto guadalupano por parte de Monroy, véase Mazín, "Dos mundos" 174.

32. Álvarez Sánchez 977-979.

33. Mazín, "Dos mundos" 182. 
suponía manejar complejas reglas de etiqueta en un contexto de facciones políticas contrastadas.

"Fracasar" al no poder evitar los escollos de tal contexto no solo ilustra frustraciones personales, sino el fin de la posibilidad de una monarquía universal española y católica. Un Nuevo Mundo socialmente más dinámico se oponía a una estructura social rígida y tradicional; una cultura étnicamente diversa y con una identidad religiosa socialmente inclusiva se oponía a otra, esencialmente monoétnica, y con una identidad religiosa impermeable a las experiencias de conversión y sincretismo. La oposición Meléndez/Vélez de León anunció la disolución de la monarquía compuesta que llegaría poco después y el divorcio cultural entre Europa y América hispana del siglo siguiente. Para el refinado e intrigante secretario, la obra del humilde y ambicioso procurador era risible y periférica. El cronista criollo, por el contrario, reconocía la originalidad de la cultura americana y le dio un lugar central en la renovación del imperio español y el catolicismo global. La frontera entre ambas visiones la había señalado un salame.

\section{Fuentes}

\section{Manuscritas}

Archivo del Ministerio de Asuntos Exteriores, Unión Europea y Cooperación de España, Madrid (MAEUECE)

Sección Santa Sede

Biblioteca Nacional de España, Madrid (BNE)

Archivo Arzobispal de Lima, Lima (AAL)

\section{Impresas}

González de Acuña, Antonio de. Informe a Nuestro Padre General de la Orden de Predicadores, Fray Joan Baptista de Marinis, le ofrece el presentado Fray Antonio González de Acuña, catedrático de Prima de Moral, Procurador de la Real Universidad de los Reyes, definidor de la Provincia de San Joan Baptista del Perú. Madrid: [s.e.],1659.

Inventario general de manuscritos de la Biblioteca Nacional. Tomo 6. Madrid: Ministerio de Educación Nacional, 1962.

Meléndez, Juan. Tesoros verdaderos de las Indias. Historia de la Provincia de San Juan Baptista del Perú del orden de Predicadores. 3 Tomos. Roma: Imprenta de Nicolás Angel Tinasio, 1681-1682.

- Vida del venerable siervo de Dios Fray Juan Masías, religioso lego del Orden de Predicadores, hijo de la gran provincia de San Juan Bautista del Perú. Roma: Imprenta de Nicolás Angel Tinasio, 1682.

- Vida, virtudes, y muerte del venerable siervo de Dios, y penitente padre Fray Vicente Vernedo. Lima: Joseph de Contreras, 1676. 
Montalvo, Francisco Antonio de. El sol del nuevo mundo: ideado y compuesto en las esclarecidas operaciones del bienaventurado Toribio arzobispo de Lima. Roma: Imprenta de Angel Bernavó, 1683.

\section{Internet}

http://dbe.rah.es/

\section{Bibliografía}

Álvarez Sánchez, Adriana. "De fraile a arzobispo. El novohispano Antonio de Monroy e Híjar (1634-1715)”. Historia Mexicana 69.3 (2020): 951-1021. Doi: 10.24201/hm.v69i3.4017.

Angulo, Domingo. Santa Rosa de Santa Maria. Estudio bibliográfico. Lima: Sanmartí, 1917.

Arbulu Barturen, María Begoña. "La fortuna de Maquiavelo en España: las primeras traducciones manuscritas y editadas de Il principe". Ingenium. Revista de Historia del Pensamiento Moderno 7 (2013): 3-28. Doi: 10.5209/ rev_INGE.2013.v7.44065.

Arias Cuba, Ybeth. "Integración de un sistema devocional indiano en la Monarquía Hispana. El culto de santa Rosa de Santa María en las ciudades de Lima y México, 1668-1737”. Tesis de doctorado en Historia, El Colegio de México, 2019.

Bennassar, Bartolomé. La monarquía española de los Austrias. Conceptos, poderes y expresiones sociales. Salamanca: Ediciones Universidad de Salamanca, 2006.

Bireley, Robert. The Refashioning of Catholicism, 1450-1700. Washington: Catholic University of America Press, 1999.

Dandelet, Thomas James. Spanish Rome, 1500-1700. New Haven / Londres:Yale University Press, 2001.

Fortea Pérez, José Ignacio. "An Unbalanced Representation: The Nature and Functions of the Cortes of Castile in the Habsburg Period (15381698)". Realities of Representation. State Building in Early Modern Europe and European America. Ed. Maija Jansson. Hampshire / Nueva York: Palgrave Macmillan, 2007.

Gálvez Peña, Carlos. "Historias religiosas como narrativas imperiales en el Perú del siglo XVII". Historia de las literaturas en el Perú. Volumen 2. Coords. Raquel Chang-Rodríguez y Carlos García-Bedoya M. Lima: Fondo Editorial Pontificia Universidad Católica del Perú / Casa de la Literatura / Ministerio de Educación del Perú, 2017.

. "Obispo, financista y político: el doctor don Feliciano de Vega y Padilla (1580-1641)". Histórica 36.1 (2012): 97-133.

. "Sueños, profecías, visiones y política en las crónicas limeñas del siglo XVII". Los sueños en la cultura iberoamericana (siglos XVI-XVIII). Eds. 
Sonia V. Rose y otros. Sevilla: Consejo Superior de Investigaciones Científicas, 2011.

. "Writing History to Reform the Empire. Religious Chroniclers in Seventeenth-Century Peru". Tesis de doctorado en Filosofia, Columbia University in the City of New York, 2012.

Lavallé, Bernard. Las promesas ambiguas. Ensayos sobre el criollismo colonial en los Andes. Lima: Pontificia Universidad Católica del Perú / Instituto RivaAgüero, 1993.

. Ed. Máscaras, tretas y rodeos del discurso colonial en los Andes. Lima: Instituto Francés de Estudios Andinos / Instituto Riva-Agüero / Pontificia Universidad Católica del Perú, 2005.

Lissón, Emilio. La Iglesia de España en el Perú.Tomo 5. Sevilla: [s.e.], 1946.

López Torrijos, Rosa. "El coleccionismo en la época de Velázquez: el marqués de Heliche". Velázquez y el arte de su tiempo. V Jornadas de Arte. Madrid: Consejo Superior de Investigaciones Científicas / Editorial Alpuerto, 1991.

Mazín, Oscar. "Dos mundos, un rey y una patria común: fray Antonio de Monroy e Hijar O.P. (1634-1715)". Cultura y arte de gobernar en espacios y tiempos mexicanos. Coords. Nelly Sigaut y Thomas Calvo. Zamora: El Colegio de Michoacán, 2015.

. "Leer la ausencia: las ciudades de Indias y las cortes de Castilla, elementos para su estudio (siglos XVI y XVII)". Historias 84 (2013): 99-110.

Nigro, Salvatore S. “The Secretary”. Baroque Personae. Ed. Rosario Villari. Chicago / Londres:The University of Chicago Press, 1995.

Plata Parga, Fernando. “Don Juan Vélez de León, refundidor de Quevedo (a propósito del romance 'Don Repollo y doña Berza')". La Perinola, Revista de Investigación Quevediana 8 (2004): 343-357.

Riva-Agüero y Osma, José de la. La historia en el Perú. Lima: Pontificia Universidad Católica del Perú, 1965.

Schilling, Heinz. Early Modern European Civilization and Its Political and Cultural Dynamism. Hannover / Londres: University Press of New England, 2008.

Tauro del Pino, Alberto. Diccionario enciclopédico del Perú. Tomo 4. Lima: Editorial Juan Mejía Baca, 1975. 